\title{
The Dream of Socialist Core Accomplishment "The Belt and Road Initiative" Practice in Colleges and Universities
}

\author{
Mingmin $\mathrm{Li}^{1,2}$ and Fangfang $\mathrm{Xie}^{1}$ \\ ${ }^{1}$ School of Marxism, Xi 'an Jiaotong University, Xi'an 710049, PR China \\ ${ }^{2}$ School of Marxism, Weinan Normal University, Weinan 714099, PR China
}

Keyword: The dream of core literacy; The Belt and Road Initiative; Strategy; Colleges and universities; Ldeological and Political Education

\begin{abstract}
The Belt and Road Initiative, it is the multilateral and bilateral economic development mechanism under the guidance of the "Silk Road Economic Belt" and "the twenty-first Century Maritime Silk Road", with the help of effective regional cooperation platform, positive development and comprehensive cooperation between countries along the line. This comprehensive national strategy is the golden age of China's modern economic development, it is also a hope of global harmony and peace, in the process of "creating a Chinese dream" and improving the core quality education of socialism, in order to cultivate college students' international thinking, this great strategic thought should be incorporated into the specific process of Ideological and political education in Colleges and universities. The Belt and Road construction of a good start, a series of gains have been achieved, The Belt and Road construction goal is to benefit the people of all countries along, and take a strategic and united vision of development, maintain the welfare level of all countries, create harmony and share with the help of the existing economic environment, jointly build an intelligent silk road, play the important role of Ideological and political education in universities, it will help future college students move towards the world with a more positive attitude.
\end{abstract}

\section{Preface}

General secretary Jinping Xi on the "The Belt and Road" strategic conception, the political background and economic background of all walks of life in China are put forward, and the construction program of national culture and other aspects, ideological and political education of college students should be fully established in the understanding of Belt and Road Initiative theory, achieve the orientation of innovation. In order to be able to achieve political trust, economic integration, cultural inclusion, to achieve the benefit community effect jointly created by the One Belt And One Road extension line, to link peace and economic development with destiny and responsibility in all countries, we should start from the basic education stage in university, establish a sound regional awareness and global development history. Therefore, in order to guarantee the goal of educating people in Colleges and universities, In the new era, carrying out ideological and political education in Colleges and universities, we must do a good job in Ideological Education of contemporary college students, finding out the problems that must be solved by ideological and political educators in Colleges and universities in the new era.

\section{The Importance of "One Belt and One Road" Thinking Learning in Colleges and Universities}

Go all Out to Realize the Chinese Dream. The Chinese dream is an important guiding ideology put forward after the 18 National Congress of the Communist Party of China, this ruling idea is to achieve the great rejuvenation of the Chinese nation, colleges and universities carry out ideological and political education work, we must focus on the greatest dream of the Chinese nation since modern times, and hope to be able to combine China's current great rejuvenation of the road of construction, take the road of socialism with Chinese characteristics. In order to carry forward the national spirit and condense China's power, therefore, we advocate the promotion of ideological and political education work is consistent with the arduous struggle. College students in the process of Ideological and political education work, a scientific world outlook and outlook on life should be shaped, under the influence of reasonable values 
and noble sentiments and EQ factors, shaping the spirit and will of college students in the future career development process. Ideological and political education in universities, it is necessary to shape students' comprehensive thinking ability, help them understand and develop innovative social leadership skills, a vivid case to help students understand the leading society, you can walk all over the world, bring China's traditional culture and advanced innovation to the world stage, realize the Chinese dream.

Understanding of Countries Along the Routes in the Internationalization Process. "Belt and Road Initiative" is the country's political strategy, at the same time, it also looks at the conflicts between war, danger and economic harmony in the current international situation, how should we call our own state power and the surrounding national power to deal with harmonious diplomacy, a bold attempt to achieve democracy and peace. In the process of internationalization, the Belt and Road to guide students to think actively around the country along in the process of internationalization, guiding students to improve their content in the process of Ideological and political education in the context of the surrounding countries, in order to extend the Silk Road Economic Belt and the interests of countries along the silk road, all efforts should be made to build a more inclusive and huge development platform and make active efforts. The ancient Silk Road used to connect China with Europe, China and South asia, and the new silk road is connected and shared through the internet, through the connection of region and network, connect the world's largest Eurasian continent into one piece. Modern ideological and political education can help college students to strengthen the cultivation of logical concept, The Belt and Road covers $64 \%$ of the world's population, GDP covering global 1/3, make the Eurasian continent glow with new vitality and vitality, it has great benefits for the world economy, therefore, in order to promote the revival of The Belt and Road along the more than 60 national economic and social development, it is the basis of guiding students to invest mutually and mutually beneficial cooperation in the future.

Philosophy of Value in Search of History and Imagination of the Future. "Belt and Road Initiative", at present, it has become the national policy of China's economic development and policy development, this is consistent with the global view of building a global integration, socialist core values to guide the international development of The Belt and Road under the guidance of the theory of learning, seeking history and imagining the future, dissolve all disputes with love and peace, the Belt and Road is a chance, improving the teaching effect of College Students' Ideological and political education, follow the development needs of life, philosophy of value cultivation, understand the political and economic differences of different countries, understand the political pursuit and essence of each country. The comprehensive development of The Belt and Road in the future will be driven from all walks of life, the cost of labor has been declining year by year, raw materials and overcapacity have been improved, The Belt and Road is a big event in the country and the world, is along the national Gongxiangshengju strong plan, The Belt and Road growth is global can solve the waste of resources and economic energy shortage of strong initiatives, increase the development of backward areas, a good beginning conducive to strategic depth development, is a good recommendation for future economic success, therefore, we should encourage the college students in the ideological and political education process must be established to carry forward, inclusive and harmonious development initiatives.

\section{Combining The Belt and Road Initiative to Carry out the University Ideological and Political Education Strategy}

Adhere to the National Harmony Theory and the Democratic Diplomatic Strategy. The silk road is mainly divided into the land Silk Road and the maritime Silk Road from the mode of transportation, the silk road has led to the harmonious development of the surrounding countries, in the process of trade and communication between goods and cultures, on the basis of democratic diplomacy and equal and just diplomacy, the barrier between goods and culture has been opened. The world today is undergoing profound and complex changes, the impact of the international financial crisis is gradually emerging, the economy is beginning to recover slowly, in the process of development and differentiation, both investment and trade show a pattern of development, carrying out ideological and political education in Colleges and universities, practice my Chinese dream, it is the process of promoting the orderly development of economic factors, promoting efficient allocation of resources and deep integration of the 
market. Therefore, combining the theory of Belt and Road Initiative, the aim is to promote the commonality of economic and political thought, hope to make college students in the level of Ideological and political education, enhance personal accomplishment and will quality, make the individual more in line with the fundamental interests of international life, highlighting the common ideas and goals of human society. Add new energy to world peace and development, this way of pursuing democracy and realizing the diversified checks and balances of countries along the route, on the road of autonomy and sustainable development, methods to promote the docking of national development strategies along the line, the potential of the regional market can be fully explored, through investment and consumption, through democracy and symbiosis, to establish a harmonious, peaceful and affluent political atmosphere.

The Belt and Road Policy Drives the Development of International Regional Vision. "The Belt and Road" strategic guidance of Ideological and political education in universities, the hope is to break the traditional direction of education, facing the cultural shock of diversity, to improve the confusion of college students in the national adaptation, this poses a great challenge to the traditional educational model, but at the same time, it has led to new ways of thinking development and ways of development, ideological and political education workers in Colleges and universities should realize the cultivation of socialist core values under the trend of the international trend, to strengthen college students for the new understanding of Belt and Road Initiative strategy, cultivating comprehensive qualities suitable for social diversity and international diversification, put an end to individualism and consumerism, broaden the traditional education scope with an open field of vision. The international regional vision needs the university students to accept the process of globalization and economy with the attitude and mind of "all embracing the sea", Hope to be in the complex and changeable international situation, Firmly occupy the commanding heights of Ideological and political education in Colleges and universities, seize the effective volume of daily learning life with keen insight, innovating the operation mode of Ideological and political work in Colleges and universities with the integration of global village and global pattern, integration with the global pattern to innovate the operation mode of Ideological and political work in Colleges and universities. Strategy development potential of the majestic Belt and Road Initiative, in order to achieve the great dream of China's solidarity with the surrounding countries, in order to promote the construction of socialist modernization continuously, need to cultivate college students' international vision, Let college students "go out" in resource competition and product competition in the future".

Take The Belt and Road as an Opportunity to Recognize the Hope of Global Peace. The purposes of international security and international peace, in order to safeguard peace and ensure the future of mankind, international security and international peace, in order to safeguard peace and ensure the future development of mankind and the core of international development goals, it has been supported by most countries and organizations in the world, maintaining international peace and eliminating racial discrimination, bring together the strength of people from all over the world, safeguarding peace and ensuring the future of the people, let the world be full of love. The people all over the world have a good desire and pursuit for peace, this is an important topic to be paid attention to in Ideological and political education, and this unity to promote the economic and political development of the purpose and mission of harmony, it has made an indelible contribution to the future of human life. Take The Belt and Road Initiative as an opportunity, in the process of politics, ideology, culture and communication in the countries along the route, create dream of peace, Ideological and political education in Colleges and universities is an important issue. Need to build a nationwide The Belt and Road, the introduction of effective resources, at the same time, the advantages of resources launched, under the background of Belt and Road Initiative, cultivating college students' hope and consciousness of establishing global peace, it is the key point of knowledge reserve and talent reserve, under the University and the Department of education requires in-depth understanding of The Belt and Road environmental social situation, economic situation, political situation and technological situation, a better understanding of the international institutional environment. Great changes have taken place in the international environment, at the same time Belt and Road Initiative along the country's domestic and international situation has changed, therefore, it is necessary to continuously improve the cognitive ability of College students, continuously strengthen its executive ability. And, hope to establish a good hope for global peace, summary The Belt and Road countries along the lessons in history and culture, contemporary political and economic development, social characteristics and social consciousness etc. , the formation of a relatively systematic knowledge and system, only know how to The Belt and Road along the country's demand and economic development logic, we can achieve the complementarity of talent gap in the global peace practice from the aspect of mechanism construction, to realize the development of international vision, change its inertia thinking and backward thinking, build a platform for innovation and entrepreneurship practice, establish an international vision and a new knowledge base.

Combine the Belt and Road Initiative National Security and Energy Strategy Education. National security is the basic interests of the state, it is an objective state maintained by a state in the absence of danger, the state can not have external threat infringement, there's no internal chaos, this is the original intention of safeguarding national security, national security includes national security, territorial security, sovereignty security, political security, military 
security, economic security and so on, at the same time, it extends to the cultural security, science and technology security, ecological security and information security within the society, and this series of security work, by the national security department special control and construction, Under the The Belt and Road Initiative strategy to ensure national security, guide college students to make positive efforts for national security and harmonious social development, it is one of the contents of Ideological and political education work. Cultivate talents with international vision, facing the gap of internationalized talents, at the same time, the ideological and political level of the national system education should be carried out, strengthening the education of national security and energy strategic reserve, it is the foundation of mutual trust, mutual respect, self protection and common maintenance of peaceful and harmonious society, college students should not only to promote the Belt and Road Initiative countries along the diversified autonomous and sustainable development from the viewpoint of social economy, at the same time, great achievements should be made in the process of reform and opening up, integrating supervision and external monitoring and governance, make positive efforts and contributions to the country's security governance and social security. Effective information sharing and common defense resources sharing, the concept of world security development guided by the basic principles of socialist Marx doctrine in various countries, connect the Eurasian continent in The Belt and Road under the guidance of adhering to the national security policy, it can make more positive efforts for the social stability and growth of the countries along the vast number of countries, make economic ties closer between countries, national security is higher. With Belt and Road Initiative thought, expanding the elements of the contemporary national security system, and the formation of a modern national security system map, under the The Belt and Road silk road connecting the leading thinking, the security interests of the countries along the lines, ensure the security of the whole country and region along the line, it is hoped that economic and environmental development will not be affected by external and internal threats, so as to ensure the state of sustained safety, security The Belt and Road along the country's cooperation and development.

\section{Concluding Remarks}

The new era of Ideological and political education has arrived, with the development of Internet and multimedia, with the "The Belt and Road strategic target of lead, ideological and political education has been put forward new requirements, in order to enhance the sense of the times and appeal, highlight the innovation and individuality of Ideological and political work, open up a new situation of Ideological and political work for college students, we must dare to break through and dare to face the students, dare to understand the new requirements of political, Ensure strict management, focus on theoretical literacy and scientific core accomplishment. Ideological and political teachers in Colleges and universities need to work hard to build the ideological and political education system, and efforts to build the students really love and lifelong benefit ideological and political education theory curriculum system, this can help the majority of college students to do a good job of patriotism education construction, do well the education of socialist core values, under the leadership of the strategic The Belt and Road, cover the excellent cultural traditions of the new theory, we are committed to building a beautiful global village.

\section{Acknowledgements}

This work was financially supported by Social science fund project of Shaanxi Province (2014E09), Shaanxi social science 2017 key projects of major theoretical and practical problems research(2017ZH007), "The 13th five-year development planning" major scientific projects of Weinan Normal University (Research on the popularization of marxism and college students' education management).

\section{Reference Documentation}

[1] Tingting Shi. The role of "two micro end" construction in Ideological and political education in Colleges and Universities[J]. Industrial \& Science Tribune, 2017, 16(24):173-174.

[2] Lujun lv. The challenge of micro culture to ideological and political education in Colleges and Universities[J]. Industrial \& Science Tribune, 2017, 16(24):199-200.

[3] Yanqing Ke. "The rule of law study and perfection of economic cooperation The Belt and Road background[J]. Modern management science, 2017, (12):82-84. 
[4] Mingyong Zhou. "The Belt and Road" talent supply: the supply of education reform and innovation of the traditional side coupling[J]. Modern management science, 2017, (12):91-93.

[5] Kui Dai. "The opportunities for development of Macao The Belt and Road construction under the background of"[J]. Modern management science, 2017, (12):33-35.

[6] Gang Wang. Re examination of the teaching reform path of Ideological and political theory course in Colleges and Universities[J]. Industrial \& Science Tribune, 2017, 16(23):159-160.

[7] Haibin Jiang. Ideological and political education in Colleges and Universities under the new situation[J]. Modern communication, 2017, (22):122-123.

[8] Jin An Analysis of how to carry out ideological education in Colleges and universities from the characteristics of new media[J]. Modern communication, 2017, (22):124-125.

[9] Xiaojing Lan. Interaction between campus tea culture construction and ideological and political education of College Students[J]. Tea in Fujian, 2017, 39(11):204-205.

[10] Yunhui Ma. The study of the ideological and Political Education under the strategy of The Belt and Road "[J]. Decision making (second half), 2017, (07):67.

[11] Yixin Zhang. "The Belt and Road" under the background of Ideological and political education exploration[J]. Journal of Shandong Agricultural Engineering College, 2017, 34(04):115-116.

[12] Dexian Li. Influence of "The Belt and Road" on the ideological and Political Curriculum Reform[J]. Gakuen, 2017, (05):99+101. 